STEPHANIE LIE LUXFORD

\title{
THE HISTORY AND DEVELOPMENT OF THE CHOICE PRINCIPLE
}

\author{
Submitted for the LLB (Honours) Degree
}

Faculty of Law

Victoria University of Wellington

2014 


\section{Abstract}

"The History and Development of the Choice Principle" is split into different categories of Australian and New Zealand cases in relation to the choice principle: dividend stripping, tax loss grouping provisions, inflated deductions, and income splitting. It considers the official position of the Inland Revenue Department on the choice principle, and sets out arguments for and against the advantages of adopting the principle in New Zealand.

Keywords: choice principle, tax avoidance, income tax 


\section{Table of Contents}

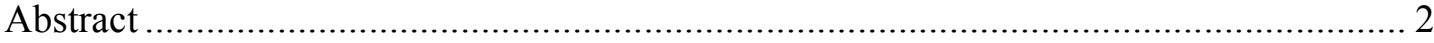

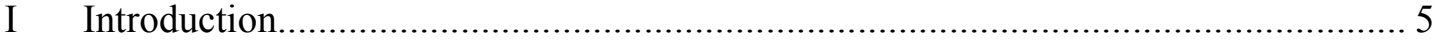

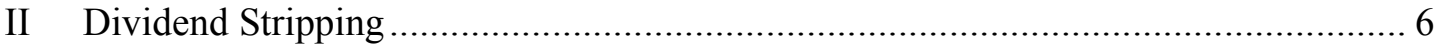

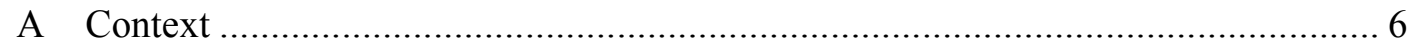

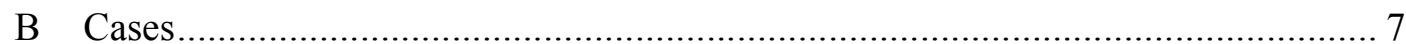

1 WP Keighery Pty Ltd v Federal Commissioner of Taxation ............................... 7

2 Newton v Federal Commissioner of Taxation ................................................... 8

3 Slutzkin v Federal Commissioner of Taxation ............................................... 10

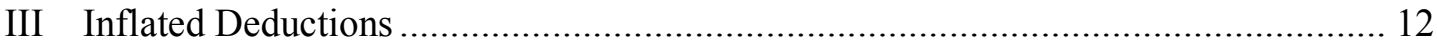

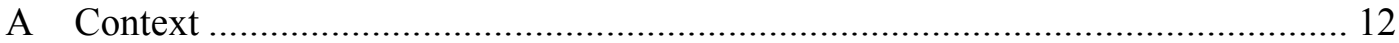

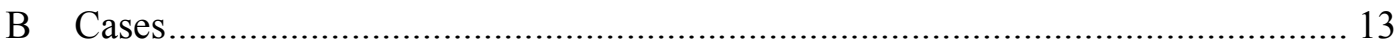

1 Cecil Bros Pty Ltd v Federal Commissioner of Taxation .................................. 13

2 Elmiger $v$ Commissioner of Inland Revenue ................................................... 15

3 Ben Nevis Forestry Ventures Ltd v Commissioner of Inland Revenue ................ 16

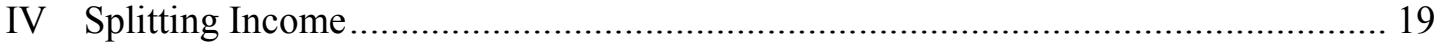

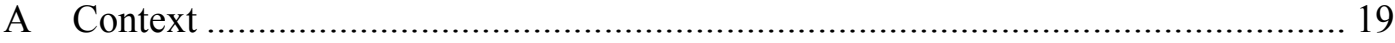

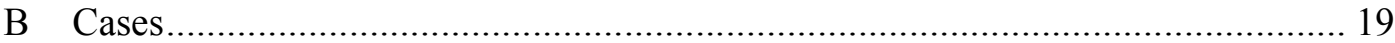

1 Peate v Federal Commissioner of Taxation ....................................................... 19

2 Mangin v Commissioner of Inland Revenue ...................................................... 20

3 Federal Commissioner of Taxation v Gulland, Watson v Federal Commissioner of Taxation, and Pincus v Federal Commissioner of Taxation ................................... 22

4 Penny v Commissioner of Inland Revenue ...................................................... 24

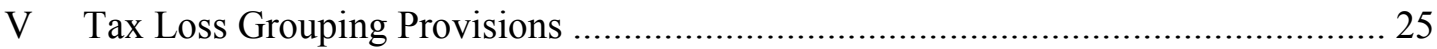

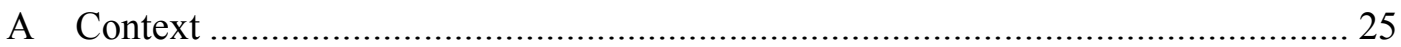

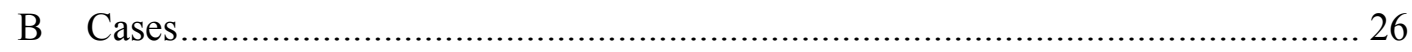

1 Commissioner of Inland Revenue v Challenge Corporation Ltd ....................... 26

2 Miller v Commissioner of Inland Revenue .................................................. 28

VI Commissioner's Position: 2013 Interpretation Statement.................................... 30

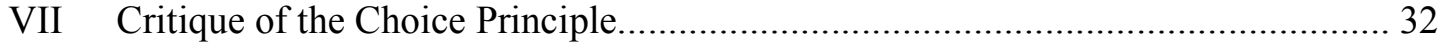

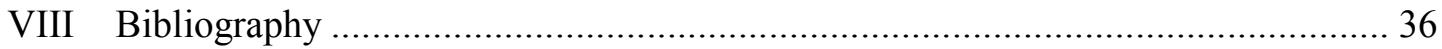

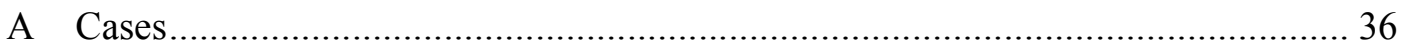

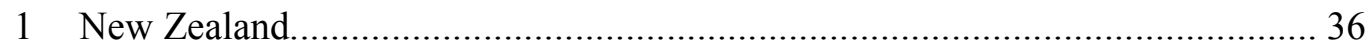




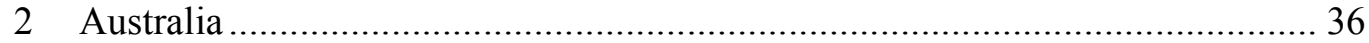

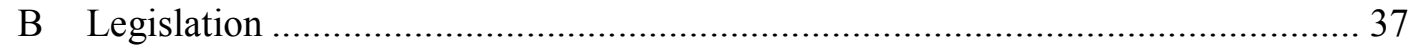

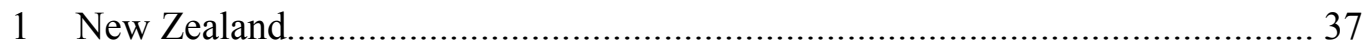

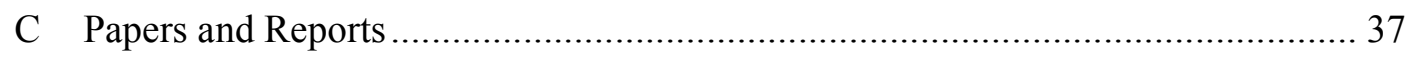

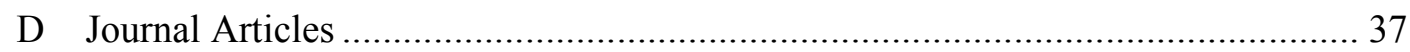




\section{The History and Development of the Choice Principle}

\section{Introduction}

The choice principle was first established by the High Court of Australia in WP Keighery Pty Ltd v Federal Commissioner of Taxation. ${ }^{1}$ The principle relates to the application of the general anti-avoidance rule (GAAR) where taxpayers have chosen to structure arrangements in a way legally open to them under legislation. In Keighery, the majority said: ${ }^{2}$

Whatever difficulties there may be in interpreting s 260 [the GAAR], one thing at least is clear: the section intends only to protect the general provisions of the Act from frustration, and not to deny to taxpayers any right of choice between alternatives which the Act itself lays open to them. It is therefore important to consider whether the result of treating the section as applying in a case ... would be to render ineffectual an attempt to defeat etc. a liability imposed by the Act or to render ineffectual an attempt to give a company an advantage which the Act intended that it might be given.

New Zealand courts have never directly applied the principle, although in a number of cases the courts have indirectly applied it. ${ }^{3}$ Australian courts applied the principle until the 1980s, after which the courts seemed to begin applying the GAAR if tax avoidance was one of the purposes of arrangements, irrespective of the choices open to taxpayers under legislation.

In parts II to $\mathrm{V}$ the paper considers the courts' treatment of the choice principle by looking at how the courts have applied the principle in different types of cases. This paper considers four categories of cases: dividend stripping, inflated deductions, income splitting, and tax

\footnotetext{
${ }^{1}$ WP Keighery Pty Ltd v Federal Commissioner of Taxation (1957) 100 CLR 66 (HCA).

2 At 109.

${ }^{3}$ For example, the dissent in Challenge Corporation Ltd $v$ Commissioner of Inland Revenue [1986] 2 NZLR 513 (PC). See pp 26-28.
} 
loss grouping provisions. Many other cases fall within the ambit of this paper, but due to the paper's restricted length, some cases have had to be excluded. Part VI sets out the official position of the Inland Revenue Department on the choice principle. Lastly, part VII concludes the paper with arguments for and against adopting the choice principle in New Zealand.

\section{Dividend Stripping}

\section{A Context}

WP Keighery Pty Ltd v Federal Commissioner of Taxation, Newton v Federal Commissioner of Taxation, ${ }^{4}$ and Slutzkin v Federal Commissioner of Taxation were cases that involved dividend stripping. ${ }^{5}$

At the time the High Court of Australia heard these cases, Australia had a classical taxation system in place, so a company's profits were taxed twice: first, when initially earned by a company, and second, when received by shareholders as dividends. This encouraged companies to retain their earnings, or find ways to distribute profits that attracted less tax. ${ }^{6}$ If private companies retained excessive amounts of profit, they had to pay a type of tax known as div. 7 tax. The New Zealand equivalent of div. 7 tax was excessive retention tax.

Public companies were not subject to div. 7 tax, because most public companies are listed, and so are run in the best interests of their shareholders. Not all public companies are listed, however, and legislative requirements in place at the time the cases in this part were heard

\footnotetext{
${ }^{4}$ Newton $v$ The Commissioner of Taxation of the Commonwealth of Australia [1958] AC 450 (PC).

${ }^{5}$ Slutzkin v Federal Commissioner of Taxation (1977) 140 CLR 314 (HCA).

${ }^{6}$ Sam Reinhardt and Lee Steel "A brief history of Australia's tax system" (2006) Australian Government The Treasury < http://archive.treasury.gov.au/documents/1156/HTML/docshell.asp?URL=01_Brief_History.asp>
} 
made it relatively easy for a private company to become a public company. Therefore, some private companies decided to become public companies to avoid having to pay div. 7 tax.

Alternately, others entered into arrangements in which shareholders sold shares of profitable companies that had large amounts of retained earnings to dividend stripping companies, essentially converting revenue receipts (dividends) into capital receipts (payment for shares).

Dividend stripping operations usually have these characteristics: ${ }^{7}$

- $[\mathrm{A}]$ target company, which had substantial undistributed profits creating a potential tax liability either for the company or its shareholders

- the sale or allotment of shares in the target company to another party

- the payment of a dividend to the purchaser or allottee of the shares out of the target company's profits;

- the purchaser escaping ... tax on the dividend so declared ... and

- the vendor shareholders receiving a capital sum for their shares in an amount the same as or very close to the dividends paid to the purchasers ... [and]

$[\mathrm{T}]$ hat they were carefully planned, with all the parties acting in concert, for the predominant if not the sole purpose of the vendor shareholders, in particular, avoiding tax on a distribution of dividends by the target company.

\section{B Cases}

\section{WP Keighery Pty Ltd v Federal Commissioner of Taxation}

In Keighery, Mr and Mrs Keighery held shares in Aquila Steel Pty Ltd. Since Aquila was a private company, if it retained excessive profits it would be liable for div. 7 tax, but if it distributed dividends, its shareholders would have to pay tax. Mr and Mrs Keighery entered

\footnotetext{
${ }^{7}$ Lawrence v Federal Commissioner of Taxation (2008) 70 ATR 376 at 61.
} 
into an arrangement that enabled a public company, WP Keighery Pty Ltd, to retain the profits of Aquila, which allowed them to avoid having to pay div. 7 tax on the profits. ${ }^{8} \mathrm{~A}$ further benefit of the arrangement was that WP Keighery Pty Ltd could distribute dividends to Mr and Mrs Keighery at a rate that ensured Mr and Mrs Keighery's income tax rates did not enter higher tax brackets. ${ }^{9}$ The Commissioner argued that WP Keighery Pty Ltd was a private company, so div. 7 tax applied, or that in the alternative the GAAR applied. ${ }^{10}$ The court held that the GAAR did not apply, ${ }^{11}$ even though the taxpayer had admitted that it had entered into the arrangement to reduce its tax liability. ${ }^{12}$ The taxpayer was entitled to choose between alternatives open to it under the Act. Applying the GAAR to the arrangement would make redundant a tax advantage Parliament intended to provide to taxpayers. ${ }^{13}$ Therefore, the GAAR did not apply, and the taxpayer was able to escape having to pay tax on retained profits.

\section{Newton v Federal Commissioner of Taxation}

In Newton, three profitable companies entered into dividend stripping operations to reduce their tax liability. The taxpayer was a shareholder in one of the companies. ${ }^{14}$ The shareholders sold their shares in the company for $£ 460,000$ to a dividend stripping company, Pactolus Ltd. Pactolus received a $£ 460,000$ dividend from the company, and then sold the shares to one of its subsidiaries for $£ 80,000$. While Pactolus had to pay tax on the dividends, because its business involved dealing in shares, it was able to deduct the $£ 360,000$ loss it had made ( $£ 460,000$ purchase price of the shares less $£ 80,000$ sale price). ${ }^{15}$ Therefore,

\footnotetext{
${ }^{8}$ WP Keighery Pty Ltd v Federal Commissioner of Taxation, above n 1, at 83-85.

${ }^{9}$ At 92.

${ }^{10}$ At 85 .

${ }^{11}$ WP Keighery Pty Ltd v Federal Commissioner of Taxation, above n 1, at 86-90.

${ }^{12}$ At 92.

13 At 92-93.

${ }^{14}$ Newton $v$ The Commissioner of Taxation of the Commonwealth of Australia, above $\mathrm{n} 4$, at 4.

${ }^{15}$ At 5.
} 
Pactolus only had to pay tax on $£ 80,000,{ }^{16}$ and the shareholders were able to avoid paying tax by converting what would have been a revenue receipt into a capital receipt. The shareholders then reinvested most of the $£ 460,000$ they had received for the shares back into the company. ${ }^{17}$ The Commissioner argued that the GAAR applied. ${ }^{18}$

Lord Denning famously held: ${ }^{19}$

$[\mathrm{T}]$ o bring an arrangement within the section you must be able to predicate - by looking at the overt acts by which it was implemented - that it was implemented in that particular way so as to avoid tax. If you cannot so predicate, but have to acknowledge that the transactions are capable of explanation by reference to ordinary business or family dealing, without necessarily being labelled as a means to avoid tax, then the arrangement does not come within the section.

The purpose of the arrangement was to increase the capital of the companies by enabling them to retain profits while avoiding div. 7 tax. ${ }^{20}$ It also enabled the shareholders to receive the money that they did not reinvest tax free, which but for the arrangement would have been a taxable dividend. ${ }^{21}$ The court applied the GAAR, and treated the entire amount paid for the shares as a dividend..$^{22}$

Lord Denning said Keighery was a case to which the predication test would not apply. ${ }^{23}$ His statement seems bizarre, however, considering Keighery was a dividend stripping case, comparable with Newton. One could easily predicate that the taxpayers in Keighery entered into the arrangement to avoid tax, as was concluded by the court in Keighery, which stated

\footnotetext{
${ }^{16}$ At 5 .

${ }^{17}$ At 6.

18 At 6.

${ }^{19}$ At 8 .

${ }^{20}$ At 6 .

${ }^{21}$ At $9-10$.

22 At 11 .

${ }^{23}$ At 9.
} 
that avoiding tax was the main, if not exclusive, purpose of the arrangement. ${ }^{24}$ The court in Newton did not discuss the choice principle, but the predication test is very different from the choice principle, focussing on economic substance over legal form. Therefore, it would seem that the choice principle and predication test are irreconcilable, and that the court in Newton impliedly rejected the choice principle.

\section{Slutzkin v Federal Commissioner of Taxation}

In Slutzkin, the taxpayer, Mr Slutzkin, held shares in a profitable holding company. ${ }^{25}$ To avoid having to pay tax on dividends, he sold his shares to a dividend stripping company. The payment he received for the shares was on capital account, so it was not taxable. ${ }^{26}$ The Commissioner argued that the GAAR applied because the payment Mr Slutzkin received was "in truth dividends" since he had effectively converted a revenue receipt into a capital receipt. ${ }^{27}$ The High Court of Australia applied the choice principle. Barwick CJ said that taxpayers may choose how to structure their assets and transactions, even if they structure them so that their tax liability is minimised: ${ }^{28}$

There is no room ... for any doctrine of economic equivalence. To the legal form and consequence of the taxpayer's transaction, which in fact has taken place, effect must be given.

Aickin J discussed Newton briefly in his judgment, declining to apply the predication test because he held that the transactions in Slutzkin did not frustrate or defeat the Act's "ordinary provisions" and so did not attract tax. ${ }^{29} \mathrm{He}$ said that even if the court did apply the predication test to the facts of Slutzkin, the GAAR would not apply because the sale of shares

\footnotetext{
${ }^{24}$ WP Keighery Pty Ltd v Federal Commissioner of Taxation, above n 1, at 109.

${ }^{25}$ Slutzkin v Federal Commissioner of Taxation, above n 5, at 314.

${ }^{26}$ At 315 .

${ }^{27}$ At 315 .

${ }^{28}$ At 319 per Barwick CJ.

${ }^{29}$ At 325 per Aikin J.
} 
was an "ordinary business dealing". ${ }^{30}$ This was based on evidence that Mr Slutzkin merely wished to sell his shares in the company. ${ }^{31}$

Slutzkin is not as dramatic a case of avoidance as Keighery, because prima facie the arrangement entered into by the taxpayer appears to be an ordinary transaction. Slutzkin is clearly an avoidance case, however, because the arrangements enabled Mr Slutzkin to avoid tax: by selling the shares without the company first distributing dividends, Mr Slutzkin received both the price of the shares and the value of the dividends in the form of a capital payment for the shares. If he had received dividends from the company first, he would have had to pay tax on the dividends because dividends are ordinarily on revenue account. ${ }^{32}$ Applying the predication test, one could predicate that Mr Slutzkin decided to sell the shares rather than receive a dividend from the company to avoid "a heavy tax liability". ${ }^{33} \mathrm{Mr}$ Slutzkin would have received part of the sale price of the shares as income via dividends, and would have to pay tax on it, so realistically he should have to pay tax on part of the sale price of the shares.

Slutzkin is an example of an endogenous avoidance case, which is case involving a seemingly ordinary business arrangement that a taxpayer has deliberately structured in a way that avoids tax. In contrast, exogenous cases involve ordinary businesses entering into transactions separate from their businesses with no purpose other than to avoid tax. Aickin J's discussion of Newton, and the supposed inapplicability of the predication test because of the ordinariness of the arrangement in Slutzkin, supports the classification of Slutzkin as an endogenous case.

\footnotetext{
${ }^{30}$ At 329 per Aikin J.

${ }^{31}$ At 329 per Aikin J.

${ }^{32}$ At 319 per Barwick CJ; at 321 per Stephen J; at 325 per Barwick CJ.

${ }^{33}$ At 321 per Stephen J.
} 
Keighery and Newton, on the other hand, are arguably exogenous cases, because in both cases the taxpayers entered into separate arrangements for the sole purpose of avoiding tax. Irrespective of the exogenous and endogenous labels applicable to the cases, however, there seems to be only one material difference between the facts of Keighery, Newton and Slutzkin. The difference is that in Keighery and Newton, the funds involved returned to the companies, whereas in Slutzkin, once the shares were sold to the dividend stripper, the funds received by the taxpayer were not returned to the company involved. In all three cases, the taxpayers avoided tax, so whether the cases were endogenous or exogenous, the courts should consistently have applied, or declined to apply, the choice principle. Moreover, the reasoning used by the judges to distinguish between the cases, such as Aickin J's reasoning for distinguishing Slutzkin from Newton, can be criticised as stipulative reasoning, because the judges merely made firm statements as to why the cases differed, without actually reasoning at all. The decisions in Slutzkin, Keighery, and Newton should not have differed. The courts should have applied the choice principle in all three cases, or not applied it at all.

\section{Inflated Deductions}

\section{A Context}

Cecil Bros Pty Ltd v Federal Commissioner of Taxation, ${ }^{34}$ Elmiger v Commissioner of Inland Revenue, ${ }^{35}$ and Ben Nevis Foresty Ventures Ltd v Commissioner of Inland Revenue are cases in which taxpayers have inflated deductions to reduce their tax liability. ${ }^{36}$ Where taxpayers incur expenses as part of their income earning processes, provided the expenses are on revenue account they are deductible. The expenses are deducted from taxpayers' gross

\footnotetext{
${ }^{34}$ Cecil Bros Pty Ltd v Federal Commissioner of Taxation (1964) 111 CLR 430 (HCA).

${ }^{35}$ Elmiger v Commissioner of Inland Revenue [1967] NZLR 161 (CA).

${ }^{36}$ Ben Nevis Forestry Ventures Ltd v Commissioner of Inland Revenue [2008] NZSC 115, [2009] 2 NZLR 289.
} 
earnings, so once deducted they lead to a reduction in assessable income. Therefore, by increasing deductions without having actually paid for the expenses claimed, taxpayers are able to reduce their assessable income and tax liability.

\section{$B$ Cases}

\section{Cecil Bros Pty Ltd v Federal Commissioner of Taxation}

The taxpayer in Cecil Bros, Cecil Bros Pty Ltd, sold shoes. ${ }^{37}$ It could have purchased the shoes from a wholesaler, but instead purchased them from a company, Breckler Pty Ltd, owned by family members of Cecil Bros shareholders for a higher price. The arrangement enabled Cecil Bros to inflate its deductions by $£ 19,777,{ }^{38}$ and Breckler made a profit of $£ 19,777 .{ }^{39}$ If one dispenses with the corporate veil, however, since Cecil Bros and Breckler were owned by members of the same family, in reality the shoes did not cost the family $£ 19,777$, because Cecil Bros paid the $£ 19,777$ and Breckler received it. The Commissioner argued that the GAAR applied. ${ }^{40}$

Dixon CJ held that since the payment from Cecil Bros to Breckler was for trading stock, the payment had to be an allowable deduction and the GAAR could not apply. ${ }^{41}$ He said that he could not identify any arrangement that the GAAR could apply to on the facts of Cecil Bros, and that the GAAR could not apply to "truly allowable" deductions. ${ }^{42}$ Menzies J said that applying the GAAR would not affect the taxpayer's tax liability, because it would not replace the contracts between the taxpayer and Breckler with contracts between the taxpayer

\footnotetext{
${ }^{37}$ Cecil Bros Pty Ltd v Federal Commissioner of Taxation, above n 34, at 433.

${ }^{38}$ At 433.

${ }^{39}$ At 433 .

${ }^{40}$ At 438 .

${ }^{41}$ At 438 .

${ }^{42}$ At 438 per Dixon CJ; at 439 per Taylor J.
} 
and the wholesaler. ${ }^{43}$ There was no evidence to suggest that the taxpayer's actual outgoings were less than the amount it paid to Breckler, or that Cecil Bros had gifted the amount to Breckler. ${ }^{44}$ Cecil Bros simply purchased shoes at a higher price than the "best price" it could have obtained. ${ }^{45}$ As a result, the court did not apply the GAAR.

Despite being heard after Newton, ${ }^{46}$ the judges in Cecil Bros do not mention the predication test. Were the predication test applied to the facts in Cecil Bros, the arrangement could have qualified as a tax avoidance arrangement. Since the GAAR at the time was an annihilating provision, Menzies $\mathrm{J}$ said that the court would have been unable to replace the contracts between Breckler and Cecil Bros with contracts between Cecil Bros and the wholesaler. ${ }^{47}$ Arguably, however, the court could have applied the GAAR by ignoring Breckler's existence. The court could have held that whatever happened within Breckler happened to Cecil Bros, with only the smaller payment recognised as having gone to the wholesaler, voiding the inflated payment. This is similar to what occurred in Elmiger ${ }^{48}$ in which the courts ignored the existence of a trust, and recognised profits as being in the hands of the Elmiger partnership instead. In legal reasoning, the whole includes the part, so surely the courts are capable of ignoring part of the whole.

The court does not discuss the choice principle in Cecil Bros, but the case seems consistent with the principle because of the court's focus on legal form over substance. This is evident in the court's unwillingness to view the arrangement as anything other than an ordinary

\footnotetext{
${ }^{43}$ At 439 per Menzies J.

${ }^{44}$ At 442 per Menzies J.

${ }^{45}$ At 442 per Menzies J.

${ }^{46}$ Newton v Federal Commissioner of Taxation, above $\mathrm{n}$ 4. See pp 8-10.

${ }^{47}$ At 442 per Menzies J.

${ }^{48}$ Elmiger $v$ Commissioner of Inland Revenue, above n 35. See pp 15-16.
} 
business dealing, albeit with the taxpayer paying a higher price than necessary for trading stock.

\section{Elmiger $v$ Commissioner of Inland Revenue}

In Elmiger, the taxpayers, the Elmiger brothers, operated an earth-moving business. ${ }^{49}$ Their very profitable business required them to use and own heavy machinery. ${ }^{50}$ They entered into an arrangement to reduce their assessable income through inflating their deductions, by setting up a family trust and selling two of their machines to it in exchange for an interestfree loan. ${ }^{51}$ The trust and the Elmigers entered into contracts which provided for the hire of the machines to the Elmigers in exchange for rent. ${ }^{52}$ The Elmigers then deducted the rent they paid each month. The rent, which comprised the trust's income, was distributed to the trust's beneficiaries or returned to the Elmigers in payment of the loan. While legally the Elmigers were paying the rent, in reality they retained most of the rent because of the arrangement, and they received a 'free' dividend that reduced their assessable income and overall tax liability. The Commissioner argued that the GAAR applied. ${ }^{53}$

The court applied the Newton predication test,${ }^{54}$ holding that the principal purpose of the arrangement was to enable the Elmigers to reduce their assessable income by inflating their deductions. ${ }^{55}$ The arrangement was incapable of explanation as an ordinary business or family dealing, ${ }^{56}$ so the GAAR applied to the arrangement. ${ }^{57}$

\footnotetext{
${ }^{49}$ Elmiger v Commissioner of Inland Revenue, above n 35, at 188.

${ }^{50}$ At 188 per McCarthy J.

${ }^{51}$ At 188 per McCarthy $\mathrm{J}$.

${ }^{52}$ At 188 per McCarthy J.

${ }^{53}$ At 176 per North $P$.

${ }^{54}$ Newton $v$ Federal Commissioner of Taxation, above n 4. See pp 8-10.

${ }^{55}$ Elmiger $v$ Commissioner of Inland Revenue, above n 35, at 6 per Turner J.

${ }^{56}$ At 183 per North $\mathrm{P}$.

${ }^{57}$ At 188 per Turner J.
} 
The choice principle is not mentioned in Elmiger, but the decision is clearly contrary to the principle in the light of statements made by the judges and their application of the predication test. ${ }^{58}$

\section{Ben Nevis Forestry Ventures Ltd v Commissioner of Inland Revenue}

In Ben Nevis, the taxpayers entered in an arrangement known as the "Trinity scheme", which enabled them to claim deductions for expenses they had not actually paid for. ${ }^{59}$ The taxpayers operated as part of a syndicate, entering into the arrangements through their agent, Southern Lakes Forestry Ltd. As part of the arrangements, Southern Lakes and Trinity 3 entered into two agreements regarding a lot within Redcliffe Station, which was land that Trinity 3 owned..$^{60}$

The first agreement provided that Trinity 3 would issue the taxpayers a licence to use the lot to conduct a forestry business in exchange for a licence premium due at the end of the licence's term. The second agreement listed the terms of the licence, set out that 484 hectares were plantable, and provided for various fees associated with the licence that the taxpayers would have to pay towards the end of the term of the licence. The agreement also required the taxpayers to plant and maintain a forest on the land, ${ }^{61}$ and pay two premiums for insurance at the beginning and end of the lease. ${ }^{62}$

The taxpayers had already incurred the licence and insurance premiums, since they were expenses incurred on an accrual basis, but they wanted to ensure that the premiums were deductible. To ensure the deductibility of the premiums, the taxpayers issued promissory

\footnotetext{
${ }^{58}$ See also Dandelion Investments Ltd v Commissioner of Inland Revenue [2003] 1 NZLR 600 (CA), a similar case to Elmiger.

${ }^{59}$ Ben Nevis Forestry Ventures Ltd v Commissioner of Inland Revenue, above n 36, at [14].

${ }^{60}$ At [16].

${ }^{61}$ At $[20]-[22]$.

${ }^{62}$ At [28].
} 
notes, which the taxpayers believed were the legal equivalent of actual payment. ${ }^{63}$ This belief was based on existing contract law cases, in which the courts had said that promissory notes were equivalent to payment. The intended effect of the arrangement was to reduce the taxpayers' tax liability by ensuring they were able to claim deductions for payments they had not actually made. ${ }^{64}$ The Commissioner argued that the GAAR applied to the arrangement to reduce the taxpayers' allowable deductions.

The majority said that when determining whether the GAAR applies, it is necessary to determine "whether the commercial reality of a transaction is consistent with its legal form". ${ }^{65}$ Transactions that use specific provisions to reduce taxpayers' tax liability will be exempt from the application of the GAAR only if Parliament intended the provisions to provide taxpayers the tax advantage claimed by them. ${ }^{66}$ The court added that specific provisions work "in tandem" with the GAAR without overriding each other, saying that Parliament must have intended the GAAR to apply in situations where the application of specific provisions has turned an arrangement into a tax avoidance arrangement. ${ }^{67} \mathrm{In}$ deciding whether an arrangement is an avoidance arrangement: ${ }^{68}$

The ultimate question is whether the impugned arrangement, viewed in a commercially and economically realistic way, makes use of the specific provision in a manner that is consistent with Parliament's purpose.

The syndicate argued that the courts should not deprive taxpayers of choices that provide taxpayers with tax benefits. ${ }^{69}$ The majority responded by saying that taxpayers may choose

\footnotetext{
${ }^{63}$ At [28].

${ }^{64}$ At [29]-[31].

${ }^{65}$ At [95].

${ }^{66}$ At [97].

${ }^{67}$ At [103]-[104].

${ }^{68}$ At [109].

${ }^{69}$ At [111].
} 
how to structure their transactions and use tax incentives, provided their transactions are permissible in the light of legislative context and purpose: ${ }^{70}$

[T] axpayers have the freedom to structure transactions to their best advantage. They may utilise available tax incentives in whatever way the applicable legislative text, read in light of its context and purpose, permits. They cannot, however, do so in a way that is proscribed by the general anti-avoidance provision.

Applying its findings to the facts of Ben Nevis, the court held that the GAAR applied because the primary purpose of the arrangement was to avoid tax. First, the taxpayers paid more for the licence than the cost of purchasing the land outright. ${ }^{71}$ Second, there was a real risk that the scheme would be unprofitable. ${ }^{72}$ Lastly, there was a timing mismatch between the point at which the taxpayers legally incurred the expenditure and when the taxpayers actually paid for it at the end of the licence. ${ }^{73}$ Evidence also showed that the insurance arrangement was circular in nature. ${ }^{74}$ Therefore, while ordinarily the taxpayers would have been able to deduct the amounts claimed, the GAAR applied because the taxpayers had taken advantage of specific provisions in a manner contrary to Parliamentary contemplation. ${ }^{75}$

The Supreme Court's decision in Ben Nevis leaves no room for the application of the choice principle. While the court says that taxpayers have a choice in $[111],{ }^{76}$ and are able to "structure transactions to their best advantage" and take advantage of tax incentives, this choice is illusory when put against the GAAR. Ben Nevis seems to indicate that unless

\footnotetext{
${ }^{70}$ At $[111]$.

${ }^{71}$ At $[121]$.

72 At $[120]$.

73 At [120].

${ }^{74}$ See [138], [144] and [148].

75 At [156].

${ }^{76}$ See quote above.
} 
taxpayers can show that their use of specific provisions in arrangements was within Parliamentary contemplation, the GAAR will apply.

\section{Splitting Income}

\section{A Context}

In Peate v Federal Commissioner of Taxation, ${ }^{77}$ Mangin $v$ Commissioner of Inland Revenue, ${ }^{78}$ Federal Commissioner of Taxation v Gulland, Watson v Federal Commissioner of Taxation, and Pincus v Federal Commissioner of Taxation, ${ }^{79}$ and Penny $v$ Commissioner of Inland Revenue, ${ }^{80}$ taxpayers split their incomes by diverting their incomes to family members. The cases involved taxpayers selling their businesses to trusts/companies and hiring out their services to the trusts/companies in exchange for salaries. The trusts/companies then continued to run the businesses as before and distributed any profits to family members, who were either shareholders or beneficiaries. This meant that the taxpayers' incomes were split between multiple people, allowing them to take advantage of the lower tax rates provided to family members with low existing incomes.

\section{B Cases}

\section{Peate v Federal Commissioner of Taxation}

In Peate, the taxpayer, Dr Peate, was part of a partnership. ${ }^{81}$ Under the partnership agreement, he received fourteen per cent of the partnership's profits. ${ }^{82}$ Each doctor in the

\footnotetext{
${ }_{77}$ Peate v Federal Commissioner of Taxation (1966) 116 CLR 38 (HCA).

${ }^{78}$ Mangin v Commissioner of Inland Revenue [1971] NZLR 519 (PC).

${ }^{79}$ Federal Commissioner of Taxation $v$ Gulland, Watson v Federal Commissioner of Taxation, and Pincus $v$ Federal Commissioner of Taxation (1985) 85 ATC 4765 (HCA).

${ }^{80}$ Penny v Commissioner of Inland Revenue [2011] NZSC 95, [2012] 1 NZLR 433.

${ }^{81}$ Peate $v$ Federal Commissioner of Taxation, above $\mathrm{n} 77$, at 40.

${ }^{82}$ At 40.
} 
partnership entered into arrangements that provided them with tax benefits. ${ }^{83}$ They dissolved the partnership, formed family companies which purchased the practices and assets of the doctors, and entered into service agreements between the family companies and an overarching company called Westbank Pty Ltd. The family companies held shares in Westbank proportionate to the profits the doctors would have received under the partnership agreement. The service agreement between the taxpayer's family company, Rayleigh Pty Ltd, and Westbank provided that all payments made directly to the taxpayers would go to the family companies. ${ }^{84}$ Any profit Rayleigh made was distributed to Mr Peate's family, who were shareholders in Rayleigh. This allowed Dr Peate to split his income, lowering the rate at which the income was taxed and decreasing the overall amount of tax paid. ${ }^{85}$ The Commissioner argued that the GAAR applied.

The court applied the GAAR, holding that Dr Peate was avoiding tax by means of the arrangement. The court taxed him as though the partnership had continued and he was receiving the practice's income directly. ${ }^{86}$ The court did not consider the choice principle, but the decision is inconsistent with the principle because of the court's clear emphasis on the importance of the substance over legal form when deciding whether to apply the GAAR.

\section{Mangin v Commissioner of Inland Revenue}

The taxpayer, Mr Mangin, owned a pastoral farm with one paddock per year in wheat. ${ }^{87}$ Every year he grew the wheat in a different paddock, and because the wheat paddock was more profitable than all of his other paddocks, he entered into an arrangement to reduce his tax liability in relation to that paddock. He had previously received all income from the

\footnotetext{
${ }^{83}$ At 42.

${ }^{84}$ At 40.

${ }^{85}$ At 42 .

86 At 43.

${ }^{87}$ Mangin v Commissioner of Inland Revenue, above n 78, at 1.
} 
wheat farm directly, but to spread his tax liability, he created a family trust to which he leased the paddock. ${ }^{88}$ The trust reimbursed Mr Mangin for his labour and expenses incurred while working the land. ${ }^{89}$ His wife and children, beneficiaries of the trust, received any remaining profits. ${ }^{90}$ The Commissioner sought to assess the income of the trust as if $\mathrm{Mr}$ Mangin had received all of it directly, arguing that the GAAR applied..$^{91}$

The majority in the Privy Council applied the GAAR to void the arrangement and increase the taxpayer's assessable income, seeming to reject the choice principle by implication. Lord Donovan did, however, state that the GAAR does not apply to all transactions that cause taxpayers' tax liability to decrease. ${ }^{92}$ In relation to the predication test from Newton, ${ }^{93}$ he said: ${ }^{94}$

In their Lordships' view this passage [the predication test], properly interpreted, does not mean that every transaction having as one of its ingredients some tax saving feature thereby becomes caught by [the GAAR] ... If a bona fide business transaction can be carried through in two ways, one involving less liability to tax than the other, their Lordships do not think s 108 [the GAAR] can properly be invoked to declare the transaction wholly or partly void merely because the way involving less tax is chosen.

As examples, Lord Donovan says that directors may have a duty to shareholders to structure transactions in ways that attract less tax, and that trustees may deliberately choose investments with tax advantages in the best interests of beneficiaries. He adds, however, that where tax avoidance is an arrangement's sole or principal purpose, the GAAR will apply. ${ }^{95}$

\footnotetext{
${ }^{88}$ At 1.

${ }^{89}$ At 1.

${ }^{90}$ At 1.

${ }^{91}$ At 5.

${ }^{92}$ At 7.

${ }^{93}$ Newton $v$ Federal Commissioner of Taxation, above $\mathrm{n}$ 4. See pp 8-10.

${ }^{94}$ At 7.

${ }^{95}$ At 7.
} 
3 Federal Commissioner of Taxation v Gulland, Watson v Federal Commissioner of Taxation, and Pincus v Federal Commissioner of Taxation

Drs Gulland, Watson, and Pincus were in partnerships. ${ }^{96}$ They dissolved the partnerships, and used trusts to split their incomes. ${ }^{97}$ They sold their practices to the trusts, continuing to operate their practices as before, but with the profits of the practices going to the trusts rather than directly to the taxpayers. The taxpayers received their salaries via service trusts that hired their services to the family trusts. ${ }^{98}$ The taxpayers, their wives, and children were the beneficiaries of the trusts. ${ }^{99}$ Although the arrangements involved trusts rather than companies, the facts of Gulland are very similar to Peate. ${ }^{100}$ The Commissioner argued that the GAAR applied. ${ }^{101}$

The High Court of Australia utilised the Newton predication test, and held that the GAAR applied. ${ }^{102}$ Gibbs CJ said that applying the GAAR to Gulland was consistent with the choice principle. This was because Keighery, and other cases that applied the choice principle: ${ }^{103}$

$[S]$ howed that the general rule enunciated by Lord Denning in $[\text { Newton }]^{104}$ is displaced when the purpose of the arrangement in question is to make use of a tax advantage for which the Act provides.

\footnotetext{
${ }^{96}$ Federal Commissioner of Taxation v Gulland, above n 79, at 64-65.

${ }^{97}$ At $64-65$.

${ }^{98}$ At 64-65.

99 At 65.

${ }^{100}$ Peate v Federal Commissioner of Taxation, above $\mathrm{n}$ 77. See pp 19-20.

${ }^{101}$ Federal Commissioner of Taxation v Gulland, above $\mathrm{n} 79$, at 66.

102 Newton v Federal Commissioner of Taxation, above n 4. See pp 8-10.

${ }^{103}$ Federal Commissioner of Taxation $v$ Gulland, above $\mathrm{n} 79$, at 71.

${ }^{104}$ Newton v Federal Commissioner of Taxation, above n 4. See pp 8-10.
} 
The taxpayers argued that the choice principle applied, because they "did no more than adopt the course, available under the Act, of creating trusts, the income of which would be taxed in accordance with [legislation]." Gibbs J rejected their argument: ${ }^{105}$

That argument ... fails because it is simply not right to say that the Act allows a taxpayer the opportunity to have his own income from personal exertion taxed as though it were income derived by a trust and held for the benefit of a number of beneficiaries.

The choice principle applies only to "give effect to a 'specific provision' of the Act", by reading down the GAAR to enable specific provisions to apply in accordance with Parliamentary intent. ${ }^{106}$ The principle does not apply to arrangements that enable taxpayers to divert their income to other taxpayers, such as occurred in the present case, Peate, and Mangin. ${ }^{107}$ The court held that the arrangements were artificial, and were not ordinary family or business dealings. Therefore, the GAAR applied. ${ }^{108}$

The dissent by Deane J in Gulland applied the choice principle and found in the taxpayers' favour. He said that whether the choice principle applies is not dependant on legislative intent, but requires courts to give effect to whatever legal form the taxpayers have chosen. ${ }^{109}$ While he would have preferred to apply the GAAR, he applied the choice principle because it was the "settled" construction of the GAAR. ${ }^{110}$

Gibbs CJ's reasoning seems to distinguish between targeted and structured avoidance. He appears to say that the choice principle applies only where taxpayers engage in targeted avoidance, which is where taxpayers deliberately structure arrangements to take advantage

\footnotetext{
${ }^{105}$ Federal Commissioner of Taxation v Gulland, above $\mathrm{n} 79$, at 71 per Gibbs CJ.

${ }^{106}$ At 80 per Brennan J.

${ }^{107}$ At 80 per Brennan J.

108 At 84 per Brennan J.

109 At 92 per Deane J.

${ }^{110}$ At 95 per Deane J.
} 
of specific provisions to reduce their tax liability. In contrast, structured avoidance is where taxpayers use fundamentally legitimate business arrangements to reduce their tax liability. Both types of avoidance ultimately rely on specific provisions, however, so Gibbs CJ's implied distinction between the two is arguably artificial. ${ }^{111}$ Moreover, the Keighery line of cases includes both structured and targeted avoidance cases, and exogenous and endogenous cases. ${ }^{112}$ Therefore, Gibbs CJ's suggestion that the choice principle only applies in targeted avoidance cases, and his conclusion that the choice principle must, as a result, be consistent with structured avoidance cases like Newton, seems incorrect. Deane J's approach, on the other hand, seems more logical, because he does not distinguish between targeted and structured avoidance.

\section{Penny $v$ Commissioner of Inland Revenue}

Penny is factually similar to Peate and Gulland. The taxpayers, Drs Penny and Hooper, were orthopaedic surgeons who sold their practices to companies, the shareholders of which were the doctors' family trusts. ${ }^{113}$ The companies hired the doctors and paid them salaries, and the remaining income of the practices was split amongst the beneficiaries of the trusts, who received the income after the companies distributed their profits to the family trusts. ${ }^{114} \mathrm{Dr}$ Hooper entered into the arrangement after the personal income tax rate increased. ${ }^{115} \mathrm{Dr}$ Penny had already structured his business in the way described prior to the increase, but once the personal income tax rate increased, the company reduced his salary significantly. ${ }^{116}$ The Commissioner argued that the GAAR applied to the arrangements. ${ }^{117}$

\footnotetext{
${ }^{111}$ See also p 34.

112 See pp 11-12.

${ }^{113}$ Penny $v$ Commissioner of Inland Revenue, above $\mathrm{n} 80$, at [1] and [2].

${ }^{114}$ At [1] and [2].

115 At [3].

116 At [3].

${ }^{117}$ At [1].
} 
The court held that the GAAR applied, because tax avoidance was one of the purposes of the arrangements. ${ }^{118}$ The taxpayers argued that they devised the arrangements for the dominant purpose of protecting themselves from negligence claims, but the court rejected this argument for various reasons, including the existence of the ACC scheme and the taxpayers' existing insurance cover. ${ }^{119}$ The taxpayers agreed that they would not have entered into such arrangements with non-family members, and that their salaries were "commercially unrealistic". ${ }^{120}$ As a result, the court applied the GAAR to void the arrangements.

\section{Tax Loss Grouping Provisions}

\section{A Context}

The taxpayers in Commissioner of Inland Revenue $v$ Challenge Corporation Ltd ${ }^{121}$ and Miller v Commissioner of Inland Revenue ${ }^{122}$ used tax loss grouping provisions to reduce their tax liability. Tax loss grouping provisions enable companies to offset their profits against losses suffered by other companies within the same group of companies. The tax loss grouping provision in the Income Tax Act 2007 is section DV 17:123

(2) To the extent set out in section FM 11, if [a] consolidated group ${ }^{124}$ would be allowed a deduction for an item of expenditure or loss as 1 company because of a nexus between the

\footnotetext{
118 At [36].

119 At [35]-[36].

120 At [16].

${ }^{121}$ Challenge Corporation Ltd v Commissioner of Inland Revenue [1986] 2 NZLR 513 (PC).

${ }^{122}$ Miller v Commissioner of Inland Revenue [2001] 3 NZLR 316 (PC).

${ }^{123}$ Income Tax Act 2007, s DV 17.

${ }^{124}$ Section FM 35 of the Income Tax Act 2007 provides that "two or more companies may choose to form a consolidated group of companies" provided the companies are "a wholly-owned group of companies" and meet eligibility requirements set out in s FM 31.
} 
expenditure and the income or carrying on of a business by another group company, a company that is part of the consolidated group is allowed a deduction.

In Challenge and Miller, the taxpayers entered into arrangements to take advantage of losses that they were not economically entitled to, and used the tax loss grouping provisions in a way outside of what was intended by Parliament. In Challenge, the taxpayer purchased a company with tax losses after the company had generated the losses. In Miller, the taxpayers sold shares to a company controlled by their promoter, Mr Russell, so that their company would become part of a group that had tax losses. In both cases, the courts held that the GAAR applied.

\section{$B$ Cases}

\section{Commissioner of Inland Revenue v Challenge Corporation Ltd}

In Challenge Corporation, the taxpayer, Challenge Corporation Ltd, purchased Perth Property Developments Ltd for $\$ 10,000$. Perth had sustained a tax loss of $\$ 5.8$ million, which Challenge attempted to use to reduce its tax liability by transferring Perth's losses to itself because they were within the same group of companies, as provided for by ss 188 and 191 of the Income Tax Act $1976 .{ }^{125}$ The Commissioner argued that the GAAR applied, while Challenge argued that the GAAR did not apply because it was using specific provisions to gain the tax advantage. ${ }^{126}$

The Court of Appeal held that the GAAR did not apply. ${ }^{127}$ The dissenting judge, Woodhouse $\mathrm{P}$, rejected the choice principle in his judgment. He said that the Newton predication test was

\footnotetext{
${ }^{125}$ Challenge Corporation Ltd v Commissioner of Inland Revenue, above n 121, at 1-6. 126 At 2 and 6.

${ }^{127}$ Challenge Corporation Ltd v Commissioner of Inland Revenue [1986] 2 NZLR 513 (CA).
} 
entirely different from the choice principle. ${ }^{128}$ Woodhouse $\mathrm{P}$ rejected the choice principle as being "not in accord with the purpose and effect intended by Parliament" for the GAAR, concluding that it should not be adopted in New Zealand. ${ }^{129}$

The Privy Council reversed the Court of Appeal decision. Lord Templeman, a member of the majority, held that the GAAR applied because the taxpayer never suffered the $\$ 5.8$ million loss, since Perth sustained the loss before it became a part of the Challenge group of companies. ${ }^{130}$ The only purpose of the agreement was to provide the taxpayer with a tax benefit through transferring Perth's loss to itself and decreasing its assessable income, ${ }^{131}$ which seems to be a clear implied rejection of the choice principle, especially when compared with other cases. ${ }^{132}$

In his dissenting judgment in the Privy Council, Lord Oliver seemed to implicitly apply the choice principle. He stated that the GAAR could not apply to the taxpayer's arrangement in Challenge, because otherwise the specific provisions relied upon by the taxpayer would be completely redundant. ${ }^{133}$ This was because the specific provisions gave the taxpayer company "options" as to how to structure its business, and this included options that enabled the taxpayer to reduce its tax liability. ${ }^{134} \mathrm{He}$ concluded that allowing the GAAR to apply without limitation to all sections of the Act would lead to absurd results, so the GAAR did not apply to the taxpayer's arrangement in Challenge. ${ }^{135}$

\footnotetext{
${ }^{128}$ At 538 .

${ }^{129}$ At 538 .

${ }^{130}$ Challenge Corporation Ltd v Commissioner of Inland Revenue, above $\mathrm{n} 121$, at 6 .

${ }^{131}$ At 6.

${ }^{132}$ For example, Federal Commmissioner of Taxation v Gulland, above n 79. See pp 22-24.

${ }^{133}$ At 14 per Lord Oliver.

134 At 14 per Lord Oliver.

135 At 15 per Lord Oliver.
} 
The majority decision reinforces the New Zealand position that the choice principle has no application, and that the GAAR applies to arrangements with tax avoidance purposes. While the minority decision does leave open the possibility that the choice principle could be applied in future where specific provisions are concerned, it is clear from other cases discussed in this paper that New Zealand courts have never adopted the choice principle, either explicitly or implicitly.

\section{Miller v Commissioner of Inland Revenue}

In Miller, the taxpayers, the Millers and the O'Neils, entered into an arrangement that reduced their tax liability. The arrangement involved taking advantage of tax loss grouping provisions. ${ }^{136}$ The taxpayers sold their shares in a company ("the taxpayers' company") to a company controlled by Mr Russell, the promoter of the scheme, with the taxpayers receiving no actual money but instead a mortgage secured over the shares. ${ }^{137}$ The taxpayers remained registered as shareholders, declaring that they held the shares in trust for $\mathrm{Mr}$ Russell's company, but the taxpayers' company continued operating as it had before the sale. ${ }^{138}$ The arrangement had the effect of making the taxpayers' company a member of a group of companies controlled by Mr Russell. ${ }^{139}$ Some of the companies in the group had tax losses, which enabled Mr Russell's company to receive profits from the company without having to pay tax on them. ${ }^{140}$ As part of the arrangement, the taxpayers' company paid, out of its profits, a regular administration charge to Mr Russell's company. Mr Russell's company retained some of each charge as payment for his services, with the

\footnotetext{
${ }^{136}$ Miller $v$ Commissioner of Inland Revenue, above n 122, at [6]-[8].

${ }^{137}$ At [6].

138 At [6].

139 At [6].

${ }^{140}$ At [6].
} 
remainder of each charge paid back to the taxpayers in instalments for the debt owed to them by Mr Russell's company for the shares. ${ }^{141}$

The Privy Council said that the scheme was "highly artificial", and was a "unitary arrangement to enable the company's net profits to be shared between the shareholders and Mr Russell."142 Lord Hoffman said that Miller was a "paradigm" of the type of arrangement to which Parliament intended the GAAR to apply. ${ }^{143}$ The arrangement provided tax benefits to various people: ${ }^{144}$

The artificial grouping of the trading company with Mr Russell's tax loss companies made the scheme viable because it enabled his companies to receive the profits without themselves becoming liable to tax. The artificial arrangements for payment by the trading company of administration and consultancy fees enabled the trading companies to eliminate their own liability to tax by claiming deductions under s 104 of the Act. And of course the primary objective of the scheme was to give the appellants the tax advantage of receiving part of the company's profits without paying income tax.

As a result, the GAAR applied. The Privy Council does not mention the choice principle in Miller, but its application of the GAAR and statements regarding the artificiality and blatant tax avoidance purpose of the arrangement make it clear that the decision impliedly rejects the choice principle.

\footnotetext{
${ }^{141}$ At [7] and [8].

${ }^{142}$ At [9] and [10].

143 At [10].

${ }^{144}$ At [11].
} 


\section{Commissioner's Position: 2013 Interpretation Statement}

The New Zealand Inland Revenue Department released an interpretation statement on sections BG 1 and GA 1 of the Income Tax Act 2007. ${ }^{145}$ Section BG 1 is the GAAR, and section GA 1 is a provision that enables the Commissioner to make adjustments following the application of the GAAR to an arrangement. The interpretation statement "outlines the Commissioner's view of the law on tax avoidance in New Zealand" and "sets out the approach the Commissioner will take" to the sections. ${ }^{146}$

The interpretation statement briefly defines and set out the history of the choice principle. ${ }^{147}$ In [508]-[510] the Commissioner explains the applicability of the choice principle after the decisions in Ben Nevis and Penny: $:^{148}$

[509] The general anti-avoidance provision proscribes arrangements that use the Act in a way Parliament did not contemplate. While taxpayers are free to structure their arrangements using structures recognised in the Act, if those structures use provisions in a way that is outside Parliament's contemplation, then the arrangement may be a tax avoidance arrangement.

She provides an example of a situation outside of Parliament's contemplation: ${ }^{149}$

For example, a taxpayer may choose to sell or lease an asset and different tax consequences will follow from that choice. If a taxpayer structures an arrangement to use the lease provisions but, when the commercial and economic reality of the arrangement is examined,

\footnotetext{
${ }^{145}$ Interpretation Statement: Tax avoidance and the interpretation of sections BG 1 and GA 1 of the Income Tax Act 2007 (Inland Revenue Public Rulings Unit, IS 13/01, 13 June 2013).

${ }^{146}$ At [1].

147 At [503]-[507].

${ }^{148}$ Ben Nevis Forestry Ventures Ltd v Commissioner of Inland Revenue, above n 36. See pp 16-19. Penny v Commissioner of Inland Revenue, above $\mathrm{n}$ 80. See pp 24-25.

149 At [509].
} 
the reality is that the arrangement is a sale, then the use of the lease provisions may be outside Parliament's contemplation.

The Commissioner then discusses Penny, and explains why the taxpayers' arrangements were outside of Parliament's contemplation:

[510] The Supreme Court in Penny (SC) said that while the taxpayers had a choice to transfer their businesses to companies owned by their family trusts (at [33]), other aspects of the arrangement meant it was still a tax avoidance arrangement. The commercial and economic reality of the arrangement, when looked at as a whole, was that the taxpayers still received the full benefit of the income and effectively derived it.

In cases like Ben Nevis and Penny, the courts recognised that the GAAR does not flow logically, and that this is necessary so that the GAAR is able to catch a wide range of avoidance arrangements. This contrasts with cases like Cridland, ${ }^{150}$ in which judges extrapolate taxpayers' ability to make choices to the extreme, using logic to justify their application of the choice principle. ${ }^{151}$ In New Zealand, Cridland would have immediately qualified as a clear case of tax avoidance to which the GAAR applied. The approach taken in Penny and Ben Nevis seems to be the correct one, despite the apparent illogicality of the GAAR and its application.

In New Zealand, the choice taxpayers purportedly have in structuring their arrangements, when put against the GAAR, is virtually non-existent, as discussed above in relation to [111] of Ben Nevis. ${ }^{152}$ The taxpayers in Ben Nevis and Penny may have been able to choose how

\footnotetext{
${ }^{150}$ Cridland v Federal Commissioner of Taxation (1977) 140 CLR 330 (HCA).

${ }^{151}$ Cridland involved a taxpayer who used specific provisions to avoid tax. He was not actually involved in primary production, but he acquired an interest in a unit trust involved in primary production so that he could benefit from specific provisions allowing primary producers to average out their incomes over a number of years.

152 See pp 16-19.
} 
to structure their affairs, but once the court held that the taxpayers entered into the arrangements for tax avoidance purposes, the GAAR overrode their choices. If the Supreme Court in Ben Nevis and Penny had applied the choice principle, as originally formulated in Keighery and applied subsequently in cases such as Slutzkin, ${ }^{153}$ the court probably would not have applied the GAAR. In Keighery, the High Court of Australia declined to apply the choice principle, despite an admission by the taxpayer of the tax avoidance purpose behind the arrangement. In Slutzkin, the court recognised the significant tax benefits gained by the taxpayer by entering the arrangement, but still held that the GAAR did not apply because legal form trumped substance. Therefore, Ben Nevis, Penny, and the Commissioner's interpretation statement seem to reject firmly any future application of the choice principle in New Zealand.

\section{Critique of the Choice Principle}

GAARs are necessary, because it would be impossible for Parliament to draft specific provisions that cover every possible tax avoidance arrangement. Taxpayers are constantly testing the boundaries of what is permissible in the context of tax avoidance, and a GAAR provides the law flexibility to combat innovative tax avoidance arrangements.

While the GAAR is effective at ensuring the government is not denied revenue from taxpayers seeking to avoid tax, it detrimentally affects the business climate because of the uncertainty GAARs unavoidably create. This uncertainty is caused by taxpayers being unsure as to whether the GAAR will apply to their arrangements because of the GAAR's undefined scope. Such uncertainty is also contrary to the rule of law, which requires laws to

${ }^{153}$ Slutzkin v Federal Commissioner of Taxation, above n 5. See pp 10-12. 
be "relatively certain in order to conform to the principles of the rule of law." 154 The choice principle removes this uncertainty by assuring taxpayers that their arrangements will not be considered tax avoidance arrangements provided they have chosen between legally available alternatives. Therefore, by rejecting the choice principle, taxpayers are denied certainty. This uncertainty may be justifiable, however, given the benefits derived from the GAAR preventing tax avoidance.

Prebble and Prebble argue that GAARs serve to uphold "the principle of horizontal equity" and ensure that tax systems are "economically neutral". ${ }^{155}$ The application of a GAAR helps to ensure that taxpayers in economically comparable positions pay tax at the same rate, ${ }^{156}$ and that the market is not distorted by taxpayers deliberately entering into arrangements solely to gain tax benefits. ${ }^{157}$ By preventing tax avoidance, the GAAR also ensures that the government is not denied the revenue needed to function, and fund services and systems such as education, healthcare, and social welfare. ${ }^{158}$ Therefore, Prebble and Prebble argue that the GAAR is necessary, despite the uncertainty it creates..$^{159}$

The Inland Revenue's interpretation statement mentioned above also discusses the necessity of the GAAR despite its effect on certainty. ${ }^{160}$ The Commissioner cites various cases, saying that Parliament has deliberately chosen not to provide certainty through enacting the GAAR ${ }^{161}$ because having "clear, bright-line rules is undesirable and impracticable in taxation law." 162 The Commissioner argues that most avoidance arrangements would fall far

\footnotetext{
${ }^{154}$ Rebecca Prebble and John Prebble "Does the Use of GAARs to Combat Tax Avoidance Breach Principles of the Rule of Law?" (2012) 2 VUWLRP 8/2012 at 28.

155 At 38 and 39.

156 At 38.

157 At 39 and 40 .

158 At 40.

159 At 40, 41 and 45.

${ }^{160}$ Interpretation Statement, above n 146. See pp 30-32.

${ }^{161}$ At [549]-[559].

162 At [552].
} 
short of qualifying as tax avoidance arrangements, with only extreme cases at risk of being caught by the GAAR, and that the law on tax avoidance provides sufficient clarity. ${ }^{163}$ She cites Ben Nevis: $:^{164}$

As in many areas of the law, there are bound to be difficult cases at the margins. But in most cases we consider it will be possible, without undue difficulty, to decide on which side of the line a particular arrangement falls.

Another reason the choice principle should not be adopted in New Zealand is the artificiality of the distinctions made by judges, such as Gibbs $\mathrm{CJ}$, when determining whether the choice principle applies. ${ }^{165}$ The artificial distinctions could lead to perverse results, and difficulties in deciding whether to apply the principle. Gibbs CJ's implied suggestion in Gulland that the choice principle applies in targeted avoidance cases but not in structured avoidance cases is bizarre, ${ }^{166}$ because if the choice principle applied only in targeted avoidance cases, the GAAR would only apply in structured avoidance cases. This would lead to the perverse result of the GAAR applying only to less obvious forms of avoidance, because targeted avoidance cases usually involve more blatant tax avoidance arrangements, while structured avoidance cases are generally more difficult to detect. ${ }^{167}$ The implied distinction made by the courts between structured and targeted avoidance, ${ }^{168}$ and the impact of whether a case is a structured avoidance case or a targeted avoidance case on whether the GAAR applies, is also illogical, as illustrated by the Cecil Bros case. ${ }^{169}$ Cecil Bros arguably involved both structured and targeted avoidance. It involved structured avoidance, because the taxpayer

\footnotetext{
163 At [557] and [559].

${ }^{164}$ At [558]. Quotation from Ben Nevis Forestry Ventures Ltd v Commissioner of Inland Revenue, above n 36 , at [112], as cited in the interpretative statement.

${ }^{165}$ See pp 11-12 and 23-24.

166 See pp 23-24.

${ }^{167}$ For example, compare the arrangements in Ben Nevis with Cridland.

168 See pp 23-24.

169 See pp 13-15.
} 
implemented a business model that inflated its deductions. It also involved targeted avoidance, because to avoid tax the taxpayer had to rely on the general permission. Therefore, arguably there is no real difference between the different types of cases. As a result, the choice principle should either apply to both structured and targeted avoidance cases, or not apply at all. If the choice principle applied in both types of avoidance, the GAAR would become redundant, however, so the only logical conclusion must be that the choice principle does not have any application.

There are clearly strong arguments in favour of the general anti-avoidance as it currently stands in New Zealand, despite the uncertainty it creates, and these arguments seem to override the need for the certainty the choice principle would provide. The choice principle would counteract the remedies to tax avoidance generated by the GAAR, and arguably have a detrimental effect on New Zealand. Potentially, adopting the choice principle into New Zealand law would affect the amount of revenue gathered by the government, allow some taxpayers to pay tax at rates lower than those paid by other taxpayers of comparable economic wealth, and cause market distortions by enabling investors to enter arrangements for the sole purpose of deriving tax benefits. The arguments mentioned above regarding targeted and structured avoidance, as well as endogenous and exogenous avoidance cases, also support the rejection of the choice principle. Therefore, the rejection of the choice principle by the courts and the Inland Revenue department is probably for the best. 


\section{Bibliography}

A Cases

$1 \quad$ New Zealand

Ben Nevis Forestry Ventures Ltd v Commissioner of Inland Revenue [2008] NZSC 115, [2009] 2 NZLR 289.

Challenge Corporation Ltd v Commissioner of Inland Revenue [1986] 2 NZLR 513 (CA).

Challenge Corporation Ltd v Commissioner of Inland Revenue [1986] 2 NZLR 513 (PC).

Elmiger v Commissioner of Inland Revenue [1966] NZLR 683 (SC).

Penny v Commissioner of Inland Revenue [2011] NZSC 95, [2012] 1 NZLR 433.

Elmiger v Commissioner of Inland Revenue [1967] NZLR 161 (CA).

Mangin v Commissioner of Inland Revenue [1971] NZLR 519 (PC).

Miller v Commissioner of Inland Revenue [2001] 3 NZLR 316 (PC).

2 Australia

Cecil Bros Pty Ltd v Federal Commissioner of Taxation (1964) 111 CLR 430 (HCA).

Cridland v Federal Commissioner of Taxation (1977) 140 CLR 330 (HCA).

Federal Commmissioner of Taxation v Gulland, Watson v Federal Commissioner of Taxation, and Pincus v Federal Commissioner of Taxation (1985) 85 ATC 4765 (HCA).

Lawrence v Federal Commissioner of Taxation (2008) 70 ATR 376 (FCA).

Newton $v$ The Commissioner of Taxation of the Commonwealth of Australia [1958] AC 450 $(\mathrm{PC})$.

Peate v Federal Commissioner of Taxation (1966) 116 CLR 38 (HCA).

Slutzkin v Federal Commissioner of Taxation (1977) 140 CLR 314 (HCA).

WP Keighery Pty Ltd v Federal Commissioner of Taxation (1957) 100 CLR 66 (HCA). 


\section{B Legislation}

1 New Zealand

Income Tax Act 1976.

Income Tax Act 2007.

C Papers and Reports

Interpretation Statement: Tax avoidance and the interpretation of sections BG 1 and GA 1 of the Income Tax Act 2007 (Inland Revenue Public Rulings Unit, IS 13/01, 13 June 2013). Sam Reinhardt and Lee Steel "A brief history of Australia's tax system" (2006) Australian Government The Treasury

$<$ http://archive.treasury.gov.au/documents/1156/HTML/docshell.asp?URL=01_Brief_Hist ory.asp $>$

\section{Journal Articles}

Rebecca Prebble and John Prebble "Does the Use of General Anti-Avoidance Rules to Combat Tax Avoidance Breach Principles of the Rule of Law?" (2012) 2 VUWLRP 8/2012.

Word count (excluding title page, abstract, table of contents, bibliographical footnotes and bibliography): 7901 . 